\title{
Környezetpolitikai diskurzus a Kínai Kommunista Párt kongresszusain előadott pártfőtitkári beszámolókban
}

\section{Bevezetés}

A hatékony környezetvédelemhez - bár alapvető fontosságú az egyéni szerepvállalás is - szükség van kormányzati szintủ stratégiára és komplex eszközrendszerre. Ezt a tudatos döntések által övezett, szakmailag megalapozott, a változásokhoz igazodó, országos szintủ távlati politikát nevezzük környezetpolitikának. Minél nagyobb egy ország, hazai környezetpolitikájának annál nagyobb globális súlya van.

Kína a világ legnépesebb, második legnagyobb nominális GDP-jével rendelkező, ${ }^{1}$ területét tekintve harmadik legnagyobb országa. Kevés olyan állam van tehát, amelynek hazai környezetpolitikája annyira meghatározó lenne az emberiség jövőjére nézve, mint Kínáé. Nagy hatással van világunkra a kínaiak környezetvédelemben való nemzetközi szerepvállalása is. Ennek hajlandóságát és mértékét kutatja jelen tanulmány a Kínai Kommunista Párt (KKP) kongreszszusain előadott pártfőtitkári beszámolókban. Az írás nem Kína környezetpolitikáját elemzi, hanem arra mutat rá, hogy az ötévente elhangzó kongresszusi beszámolókban hogyan jelenik meg ez a terület.

\section{A Kínai Kommunista Párt kongresszusainak fontossága}

A pártkongresszusok több okból is rendkívüli jelentőséggel bírnak. Először is, itt történik a vezetőváltás: az idős kádereket nyugdíjazzák, és megválasztják a nagyjából kétszáz fős Központi Bizottságot, amely a kongresszus után megtartja első plénumát, ahol kinevezik a KKP legfő́bb vezetőit, beleértve a Politikai Bizottságot, annak Állandó Bizottságát és azzal együtt természetesen

${ }^{1}$ A Világbank adatai alapján: https://data.worldbank.org/indicator/NY.GDP.MKTP.CD?most_ recent_value_desc=true. 
a pártfőtitkárt (hivatalosan a Kínai Kommunista Párt Központi Bizottságának fötitkárát) is. ${ }^{2}$

Másodszor, csak a pártkongresszus módosíthatja a pártalkotmányt. A jelenleg hatályos pártalkotmányt 1982-ben, a 12. kongresszuson fogadták el, és azóta több kongresszus végzett rajta módosításokat. ${ }^{3}$

Végül, a kongresszus a KKP hierarchiáján belüli leginkább irányadó gyűlés, amelyen kijelölik a fö politikai irányvonalat a legközelebbi kongresszusig, tehát az 1970-es évek óta a következő öt évre. Az iránymutatás a párt legkülönbözőbb szintjeiről érkező mintegy 2000 delegált előtt, egy politikai beszámoló formájában hangzik el. Ezt ugyan a pártfötitkár mondja el, ezen azonban nem a személyes vélemény hangoztatását kell érteni, hanem „egy szintetikus dokumentumot, amely tükrözi a szélesebb pártvezetés egyetértését". ${ }^{4}$ A nagyjából egyhetes kongresszus zárását követően a vezetők csak a beszámolóban kijelölt stratégiával összhangban intézkedhetnek, illetve a pártalkotmány szerint a politikai irányvonal módosítására csupán az évente legalább egyszer ülésező, nagyjából kétszáz fös Központi Bizottságnak van joga. ${ }^{5}$

\section{A környezetvédelem története Kínában}

1972-ben Stockholmban Kína részt vett az ENSZ Konferencia az emberi környezetről címü első világméretü környezetvédő gyülésen, ez jelentette a kínaiak első zöld lépését. A kínaiak egy évvel később megalapították az első országos környezetvédelmi hatóságot, és megtartották az első nemzeti konferenciájukat. Ekkorra a folyók és a nagyvárosok már szennyezettek voltak. Ezt követően környezetvédő testületek alakultak, majd 1979-ben kiadták az első rendeletet a környezetvédelemröl. ${ }^{6}$

1982-ben az alkotmány 9. pontjában rögzítették: „Az állam védi a természeti erőforrások észszerű felhasználását, védi a ritka állatokat és növényeket. Bármely szervezet vagy magánszemély számára tilos a természetes erőforrások bármilyen módon történő megsértése vagy károsítása" (国家保障自然资源的合理 利用, 保护珍贵的动物和植物。禁止任何组织或者个人用任何手段侵占 或者破坏自然资源). A 26. pont szerint: „Az állam védi és fejleszti az élet- és ökológiai környezetet, megakadályozza a szennyezést és az egyéb káros hatáso-

\footnotetext{
${ }^{2}$ Institute for Security \& Development Policy: https://isdp.eu/publication/nccpc-nationalcongress-communist-party/

3 Jordán 2015.

${ }^{4}$ Miller 2012: 2.

5 Miller 2012: 2.

${ }^{6}$ Kusai 2020: 17.
} 
kat. Az állam szervezi és ösztönzi a faültetést és az erdőtelepítés, védi az erdőket” (国家保护和改善生活环境和生态环境, 防治污染和其他公害。国家 组织和鼓励植树造林, 保护林木). ${ }^{7}$ 1983-ban a népességszabályozás mellett a környezetvédelmet tették a két alapvető állami politikává, kijelentve, hogy a környezeti problémák legalább olyan súlyosak, mint a túlnépesedés veszélye. A világ többi részével lépést tartva, 1987-ben, megjelenése után szinte azonnal lefordították kínaira az ENSZ Közös jövőnk címü jelentését, amely lefektette a fenntartható fejlődés elméletét. ${ }^{8}$

A környezet megóvásáért folytatott munka következö fontos állomása 1992 volt, amikor két hónappal az ENSZ Rio de Janeiróban rendezett Környezet és Fejlődés konferenciája után kiadták Kína tízpontos stratégiai környezetvédelmi és fejlesztési programját (中国环境与发展十大对策). Ebben bejelentették, hogy Kína a fenntartható fejlődés (可持续发展 ke chixu fazhan) stratégiáját alkalmazza. ${ }^{9}$ 1993-ban összeült az ipari szennyezés megelözéséről és szabályozásáról szóló második nemzeti konferencia (第二次全国工业污染防治工作会 议) is. ${ }^{10} \mathrm{~A}$ következő évben, a világon elsőként a kínaiak adták ki a XXI. századi környezetvédelemre irányuló tervezetüket (Kína XXI. századi programja-Fehér könyv a XXI. század kínai népességéről, környezetéről és fejlődéséről 中国21世 纪议程一一国 21 世纪人口、环境与发展白皮书). ${ }^{11}$ Meg kell említeni, hogy a tervezet feltünően gyorsan született meg a riói konferencia után: 1994 áprilisára már készen is voltak vele. A prezentálására Pekingben, 1994 júliusában került sor nemzetközi kormányok és szervezetek hivatalos képviselői előtt. Képviseltette magát többek közt a Világbank és az Ázsiai Fejlesztési Bank is. Bradbury és Kirkby szerint ,a magas szintü beszámoló célja az volt, hogy erősítsék Kína esélyeit nemzetközi kölcsönökre és egyéb támogatási formákra". ${ }^{12}$

1996-ban a fenntartható fejlődést a nemzeti stratégia részévé tették, és elkezdődött ennek kivitelezése. ${ }^{13}$ Ez idő alatt Kína GDP-jének 0,93\%-át (mintegy 346 milliárd jüant) a környezetszennyezés csökkentésére fordította, ${ }^{14}$ ez még tükrözi a környezetvédelmi harc kezdetén felállított prioritást, amely szerint elsődleges a szennyezés visszaszorítása.

${ }^{7}$ A Kínai Népköztársaság Alkotmánya: http://www.gov.cn/govweb/test/2005-06/14/content_ 6310.htm.

${ }^{8}$ Zhang-Wen-Peng 2007: 2.

${ }^{9}$ Zhang-Wen-Peng 2007: 2.

${ }_{10}$ Zhang-Wen 2008: 1251.

11 Zhang-Wen-Peng 2008: 131.

${ }_{12}$ Bradbury-Kirkby 1996: 98.

13 The People's Republic of China National Report on Sustainable Development: 2. http:// download.china.cn/en/pdf/development2.pdf

${ }^{14}$ Wang 2010: 1207. 
Jóllehet korábban a szennyezés ellen vívott harc dominált, az 1998-as nagy árvíz felhívta a figyelmet az ökológiai rendszer fenntartásának, a környezeti romlás visszaszorításának, a biodiverzitás megőrzésének a fontosságára. ${ }^{15}$ A 2000-es évektől aztán a környezetvédelmi intézkedések és rendeletek száma egyre növekedett. Például az Államtanács jóváhagyta az ökológiai környezetvédelem nemzeti irányelveit (2000); az Államtanács kiadta a forgalomból kivont autók újrafeldolgozására vonatkozó rendelkezést (2001); az Államtanács kiadta a meredek szántóföldek erdőkké és gyepekké történő visszaalakításáról szóló rendeleteket (2002); megszületett a radioaktív szennyezés megelőzéséről és ellenőrzéséről szóló törvény (2003); az Állami Környezetvédelmi Igazgatóság és a Nemzeti Statisztikai Hivatal közösen megszervezte a zöld GDP kutatását (2004); kihirdették a megújuló energia támogatásáról szóló törvényt (2005) stb. ${ }^{16}$ Wang 2007-es tanulmányában megjegyzi: „A környezetvédelem jogi keretének kidolgozása érdekében lenyügöző munka történt. Ma már általánosan elfogadott tény, hogy Kína környezetvédelmi törvényei viszonylag teljesek, és hogy a végrehajtás most az igazi probléma. Ez részben igaz. Ugyanakkor, hasonlóan a korai amerikai környezetvédelmi törvényekhez, Kína környezetvédelmi törvényei, bár széles körü lefedettséggel rendelkeznek, továbbra is olyan hiányosságokkal küzdenek, amelyek korlátozzák a hatékonyságukat. A rendelkezések gyakran homályosak, és jobban hasonlítanak politikai nyilatkozatokhoz. Inkább »ösztönöznek«, mint »megkövetelnek«. A legfontosabb pedig talán az, hogy a végrehajtási rendelkezések gyakran rendkívül gyengék." ${ }^{17}$ A jogi kereteket a környezetvédelemhez tehát már a 2000-es évek elején lefektették, azok azonban több ponton is hagytak kívánnivalót maguk után.

A belső intézkedések mellett Kína a riói konferencia után folyamatosan mélyítette nemzetközi együttmüködéseit a környezetvédelem területén. A 2001es év fontos állomás volt ezen a téren: Kína a Kereskedelmi Világszervezet (WTO) teljes jogú tagjává vált. Már a Marrakesh-ben aláírt alapító okiratban kijelölték, hogy a WTO alapvető céljai közé tartozik a fenntartható fejlődés és a környezetvédelem. ${ }^{18}$ Ugyanebben az évben kiadták a tizedik ötéves tervet is (2001-2005), amely 700 milliárd jüenes keretet állapított meg a városi és a vidéki környezetfejlesztésre. ${ }^{19}$

A 2008-as olimpiai év számos környezetvédelmi intézkedést hozott föleg Pekingben és környékén. A ,zöld olimpia, csúcstechnológiás olimpia, az embe-

15 Wang 2010: 1207.

${ }_{16}$ Zhang-Wen 2008: 1251.

17 Wang 2007: 203.

${ }_{18}$ WTO álláspontja a kereskedelem és a környezet kapcsolatáról: https://www.wto.org/ english/tratop_e/envir_e/envir_e.htm.

${ }^{19}$ Han 2002 (online). 
rek olimpiája” (绿色奥运, 科技奥运, 人文奥运) szlogennek megfelelően Kína célja az volt, hogy környezetbarát ötkarikás játékokat rendezzen. Ennek érdekében felállították a Környezetvédelmi Minisztériumot (2018 óta Ökológiai és Környezetvédelmi Minisztérium), és elrendelték, hogy a gyáraknak 30\%-kal kell csökkenteniük károsanyag-kibocsátásukat, a túlságosan szennyező gyárak müködését pedig korlátozták vagy beszüntették. Szabályozták a közlekedést is: 50\%-kal csökkentették a személyautók számát az utakon, az EURO-I környezetvédelmi besorolást el nem érő jármúveket pedig teljesen kitiltották Pekingből. A szálló por csökkentése érdekében átmenetileg leállították az építkezési munkálatokat. Összességében azonban az olimpiai előkészületek csak átmeneti pozitív hatással voltak a környezetre. ${ }^{20}$

A környezetvédelem, a szennyezés csökkentése megjelent a későbbi ötéves tervekben is. A tizenegyedikben (2006-2010) huszonkét területre fogalmaztak meg terveket, ezek közül tizennégynek elvárt, nyolcnak pedig kötelező érvényü célja volt. A nyolc kötelező közül négy közvetlenül a környezethez kapcsolódott. A 2005-ös adatokhoz viszonyítva 2010-re az alábbiakat kellett megvalósítani: a kén-dioxid-kibocsátás csökkentése 10\%-kal, az energiafelhasználás csökkentése $20 \%$-kal, a vízhasználat csökkentése az iparban 30\%-kal, a termőföldterületek csökkentése 0,2 millió hektárral, az erdők területének növelése 1,8\%-kal. ${ }^{21}$

A tizenkettedik ötéves tervben (2010-2015) bejelentették, hogy a fent megnevezett célkitüzéseket megvalósították, sőt a kén-dioxid-kibocsátás 10\%-ban megjelölt határát túllépve, 14,29\%-os csökkenést sikerült elérni. A további fö célok a következők voltak: a 2010-es adatokhoz képest 2015-re a KOI (kémiai oxigénigény) 8\%-os csökkentése, az ammóniakibocsátás 10\%-os csökkentése, a kén-dioxid-kibocsátás $8 \%$-os csökkentése, a nitrogénoxid-kibocsátás 10\%-os csökkentése. ${ }^{22} \mathrm{~A}$ tizenkettedik ötéves terv alatt a pártkongresszus a környezetvédelem fontos platformjává válik, legitimálja a környezetpolitika létjogosultságát, és párt-, valamint állami szinten is a legfontosabb stratégiai szférák közé emeli.

2011-ben elkezdődött az 1979-ben hozott környezetvédelmi rendelet átdolgozása is. Időszerủ volt már, hiszen a törvény utoljára 1989-ben esett át kisebb módosításon. A javításra, mint korábban említettem, a jogi szövegezés gyengesége miatt igencsak szükség volt. A törvény végül 2015-ben, négy felülvizsgálat után - amelyben nemcsak környezetvédelmi jogi szakértők, kormányzati testületek és a helyi környezetvédelmi hivatalok vettek részt, hanem kétszer még a közvéleményt is bevonták - látott napvilágot. Korábban a cégeknek jobban

${ }^{20}$ Cao-Hidemichi-Shunsuke 2013.

${ }^{21}$ A 11. ötéves terv, 6. rész 22. fejezet: https://www.ndrc.gov.cn/xwdt/gdzt/ghjd/quanwen/ 201402/t20140219_1201612.html.

22 A 12. ötéves terv környezetvédelmi vonatkozása, 1. rész: http://www.cn-hw.net/html/sort 056/201201/31655.html. 
megérte még a maximális bírságot is kifizetni, mint kibocsátáscsökkentő berendezést alkalmazni, az új törvénynek köszönhetően azonban már nem olcsóbb kifizetni a bírságot, mint betartani a környezetvédelmi elöírásokat. Az állam továbbá már polgárainak is nagyobb szerepet szán a zöld mozgalomban. ${ }^{23}$

A 2015-től indult szigorúbb környezetvédelmi eljárások a korrupcióellenes harc részei is. Ezzel párhuzamosan a tizenharmadik ötéves terv (2015-2020) is kiterjedt környezetvédelmi terveket fogalmazott meg. Külön kiemelendő a tervezetben is rögzített álláspont a globális klímaváltozás terén vállalt nemzetközi együttmüködésről:

Ragaszkodva a közös, de differenciált felelősség alapelvéhez, az igazságosság alapelvéhez és ahhoz az alapelvhez, hogy mindenkinek a saját képességei szerint kell szerepet vállalnia, aktívan vállaljuk a nemzetközi kötelezettségeket, amelyek országunk alapvető állapotának, fejlettségi szintjének és gyakorlati képességeinek megfelelnek. Biztosítjuk, hogy megtegyük saját hozzájárulásunkat a klímaváltozásra adott erőteljesebb válaszhoz. Aktívan részt veszünk a globális klímaváltozással kapcsolatos tárgyalásokon, előmozdítjuk az igazságos, észszerü, közös nyereségen alapuló globális klímakormányzási rendszer kiépítését. Elmélyítjük a klímaváltozással kapcsolatos multilateriális párbeszédet és pragmatikus együttműködést. Teljes mértékben alkalmazzuk a Dél-Dél Együttmüködési Alap szerepét, és támogatunk más fejlődő országokat abban, hogy erősíteni tudják a klímaváltozásra való reagálási képességüket (13. ötéves terv. X. rész, 46. fejezet, 3. pont).

坚持共同但有区别的责任原则、公平原则、各自能力原则, 积极承担与我 国基本国情、发展阶段和实际能力相符的国际义务, 落实强化应对气候变 化行动的国家自主贡献。积极参与应对全球气候变化谈判, 推动建立公平 合理、合作共赢的全球气候治理体系。深化气候变化多双边对话交流与务 实合作。充分发挥气候变化南南合作基金作用，支持其他发展中国家加强 应对气候变化能力。24

Mindenképpen észben kell tartanunk a fenti sorokat, amikor a kínai környezetvédelemről van szó. Kína fejlődő ország, és bár kész szerepet vállalni a környezet megóvásáért folytatott világméretü harcban, a felelösség közös, a feladatokat meg kell osztani („differenciált felelősség alapelve”), amelyekben a fejlett, gazdag országoknak nagyobb részt kell vállalniuk („,mindenkinek a saját képességei szerint kell szerepet vállalnia").

\footnotetext{
23 Ker - Logan 2014 (online).

24 13. ötéves terv: http://www.12371.cn/special/sswgh/wen/\#10.
} 


\section{Környezetvédelem a Kínai Kommunista Párt kongresszusain előadott pártfötitkári beszámolókban}

A kínai környezetpolitika fejlődésének és jelentősebb eseményeinek bemutatása után áttekintem, miként kommunikálja a KKP legfelsőbb testülete a környezet megóvásának fontosságát, hogyan közvetíti a környezettudatosság szellemét. A releváns részeket fordításban közöljük, és feltüntetjük az aktuális pártfötitkár nevét is.

A környezetvédelem a 13. kongresszus (1987. október 25. - november 1.) óta szerepel a pártfötitkári beszámolókban. A 13. kongresszuson a környezetvédelem mindössze két mondatban, kirakatjelleggel tünt föl. Jelentősége és szerepe is csak a fentebb említett az ENSZ Közös jövőnk címü jelentés fordításához mérhető.

A gazdaságépítés előremozdításakor nagy erőkkel kell védeni és észszerủen kell felhasználni mindenféle természeti erőforrást, törekednünk kell a környezetszennyezés átfogó kezelésének kiterjesztésére, fokozottabban kell védeni az ökológiai környezetet, megfelelően kell összefüznünk a gazdasági, társadalmi és környezeti elönyöket.

在推进经济建设的同时, 要大力保护和合理利用各种自然资源, 努力开展 对环境污染的综合治理, 加强生态环境的保护, 把经济效益、社会效益和 环境效益很好地结合起来。(13. kongresszus, 赵紫阳 Zhao Ziyang)

Itt még különösképpen ki kell emelni, hogy a népességszabályozás, a környezetvédelem és az ökológiai egyensúly kapcsolódik a gazdaság és a társadalom fejlödésének valamennyi fontos kérdéséhez.

这里还要特别指出, 人口控制、环境保护和生态平衡是矢系经济和社会发 展全局的重要问题。(13. kongresszus, 赵紫阳 Zhao Ziyang)

A 14. kongresszuson (1992. október 12-18.) szintén történt némi utalás a természet megóvásának fontosságára.

Folyamatosan javítani kell a nép életét, szigorúan szabályozni kell a népességnövekedést, fokozottabban kell védeni a környezetet.

不断改善人民生活, 严格控制人口增长, 加强环境保护。(14. kongresszus, 江泽民 Jiang Zemin)

Lelkiismeretesen kell kiviteleznünk a népességnövekedés szabályozására és a fokozottabb környezetvédelemre vonatkozó alapvető nemzeti politikát. A népességszabályozási programon egyáltalán nem szabad lazítanunk, minden- 
képpen biztosítani kell a népességkorlátozás kitüzött céljának megvalósítását, ragaszkodnunk kell a jobb gyermekek születéséhez és neveléséhez, emelnünk kell a népesség minőségét. Nagy figyelmet kell szentelnünk a népesség elöregedését érintő kutatásoknak, szorgalmasan kell tennünk azért, hogy jól végezzük el a munkát ezen a területen. Növelnünk kell az egész nemzet környezettudatosságát, meg kell védenünk és észszerủen kell használnunk a földeket, az ásványianyag-forrásokat, az erdőket, a vizet és valamennyi természeti erőforrást, szorgalmasan kell javítanunk az ökológiai környezetet.

认真执行控制人口增长和加强环境保护的基本国策。计划生育工作决不能 放松, 必须确保实现既定的人口控制目标, 坚持优生优育, 提高人口质 量。重视研究人口老龄化问题, 认真做好这方面的工作。要增强全民族的 环境意识, 保护和合理利用土地、矿藏、森林、水等自然资源, 努力改善 生态环境。(14. kongresszus, 江泽民 Jiang Zemin)

A 15. kongresszuson (1997. szeptember 12-18.) a pártfötitkári beszédben az előzőnél valamivel több szó esett a környezetvédelemről, számos területét érintve a komplex problémakörnek. Megfogalmazódik továbbá a fenntartható fejlődés stratégiája a modernizáció építésében.

Tisztán látjuk, hogy az előttünk álló úton nem kevés ellentmondás és nehézség van, a munkában vannak gyengeségek és hiányosságok. Legföképpen: [...] a gazdaság fejlődése az erőforrásokra és a környezetre hatalmas nyomást gyakorol... 我们清醒地看到, 在前进道路上还有不少矛盾和困难, 工作中也有缺点 和不足。主要是 : [......] 经济发展给资源和环境带来巨大的压力... (15. kongresszus, 江泽民 Jiang Zemin)

Hazánk népes, erőforrásunk azonban nem elég, a modernizáció építésekor a fenntartható fejlődés stratégiáját kell követnünk. Ragaszkodnunk kell a népességszabályozási programra és a környezetvédelemre vonatkozó alapvető nemzeti politikához, helyesen kell kezelnünk a gazdasági fejlődés kapcsolatát a népességgel, az erőforrásokkal és a környezettel. Az erőforrás-fejlesztés és takarékosság egy időben történik, ezek közül a takarékosságot kell az első helyre tenni, és javítanunk kell az erőforrás-felhasználás hatékonyságát. Átfogóan kell megtervezni a földek és az erőforrások fejlesztését és javítását, szigorúan kell végrehajtanunk a földek, vizek, erdők, ásványok, tengerek és mindennemű erőforrások használatáról és védelméről szóló törvényeket. Meg kell valósítanunk az erőforrások fizetés ellenében történő használatát. Erősítenünk kell a környezetszennyezésre vonatkozó kormányzást, fákat kell ültetnünk, és füvet kell vetnünk, jó munkát kell végeznünk a vizek és a földek megvédéséért, meg kell gátolnunk az elsivatagosodást, javítanunk kell az ökológiai környezetet. Szabályoznunk kell 
a népességnövekedést, emelnünk kell a népesség minőségét, és nagy figyelmet kell szentelnünk a népességelöregedés problémájának.

我国是人口众多、资源相对不足的国家, 在现代化建设中必须实施可持续 发展战略。坚持计划生育和保护环境的基本国策, 正确处理经济发展司人 $\square$ 、资源、环境的矢系。资源开发和节约并举，把节约放在首位，提高资 源利用效率。统筹规划国土资源开发和整治, 严格执行土地、水、森林、 矿产、海洋等资源管理和保护的法律。实施资源有偿使用制度。加强对环 境污染的治理，植树种草，搞好水土保持，防治荒漠化，改善生态环境。 控制人口增长, 提高人口素质, 重视人口老龄化问题。(15. kongresszus, 江 泽民 Jiang Zemin)

A fent részletezett eseményekkel párhuzamosan (környezetvédelmi intézkedések és rendeletek, csatlakozás a WTO-hoz) a 16. kongresszuson (2002. november 8-14.) Jiang Zemin pártfötitkár hangsúlyozta az ember és a környezet közti harmónia fontosságát és azt, hogy a felvilágosult fejlődés útjának része az ökológiai környezet javítása is.

Ragaszkodnunk kell ahhoz, hogy a gazdaság építése a legfontosabb, a fejlödés módszerével kell megoldanunk az előttünk álló problémákat. A fejlődés a szilárd út. Meg kell ragadnunk minden lehetőséget a fejlődés felgyorsítására. A fejlödésnek új gondolkodás szerint kell megvalósulnia. A belső szükséglet kiterjesztésének irányvonalához kell ragaszkodnunk, véghez kell vinnünk a tudományon és az oktatáson keresztül az ország felemelését, valamint a fenntartható fejlődés stratégiáját, meg kell valósítanunk a gyorsaság és a struktúra, minőség, hatékonyság egységét, valamint a gazdasági fejlődés és a népesség, erőforrások, környezet harmóniáját.

坚持以经济建设为中心, 用发展的办法解决前进中的问题。发展是硬道 理。必须抓住一切机遇加快发展。发展要有新思路。坚持扩大内需的方 针, 实施科教兴国和可持续发展战略, 实现速度和结构、质量、效益相 统一，经济发展和人口、资源、环境相协调。(16. kongresszus, 江泽民 Jiang Zemin)

Be kell látnunk, hogy országunk most és még hosszú ideig a szocializmus kezdeti szakaszában van, a most elérendő mérsékelt jómód még mindig alacsony színvonalú, nem teljes körü és nagyon egyenetlen fejlődésü. Az emberek napról napra növekedő anyagi kulturális szükséglete és a társadalmi termelés elmaradottsága közti ellentét még mindig hazánk társadalmának legnagyobb ellentéte. Hazánk termelési ereje és technológiája, oktatása még mindig viszonylag elmaradott, az iparosodás és a modernizáció megvalósításáig még hosszú utat kell 
megtennünk; [...] az ökológiai környezet, a természeti erőforrások és a gazdasági, társadalmi fejlődés ellentéte napról napra világosabb [...].

必须看到, 我国正处于并将长期处于社会主义初级阶段, 现在达到的小康 还是低水平的、不全面的、发展很不平衡的小康, 人民日益增长的物质 文化需要同落后的社会生产之间的矛盾仍然是我国社会的主要矛盾。我 国生产力和科技、教育还比较落后, 实现工业化和现代化还有很长的路 要走 $; \ldots . .$. 生态环境、自然资源和经济社会发展的矛盾日益突出... (16. kongresszus, 江泽民 Jiang Zemin)

A fenntartható fejlődésre való képességünket folyamatosan erősíteni, az ökológiai környezetet javítani, az erőforrás felhasználásának hatékonyságát észrevehetően növelni kell, az emberek és a környezet közti harmóniát elöre kell mozdítani, előbbre kell vinnünk az egész társadalmat a termelés emelésének, az élet gazdagításának, az ökológia javításának civilizált, fejlődő útján.

可持续发展能力不断增强, 生态环境得到改善, 资源利用效率显著提高, 促进人与自然的和谐, 推动整个社会走上生产发展、生活富裕、生态良好 的文明发展道路。(16. kongresszus, 江泽民 Jiang Zemin)

Ragaszkodnunk kell ahhoz, hogy az információalapúvá válással vezessük az iparosodást, és az iparosodással mozdítsuk előre az információalapúvá válást, egy olyan új típusú iparosítási úton haladjunk, amely bővelkedik tudományostechnológiai elemekben, jó gazdasági hatékonyságú, erőforrás-felhasználása alacsony, kevés környezetszennyezéssel jár, és teljes mértékben alkalmazza az emberi erőforrás elsőbbségét.

坚持以信息化带动工业化, 以工业化促进信息化, 走出一条科技含量高、 经济效益好、资源消耗低、环境污染少、人力资源优势得到充分发挥的新 型工业化路子。(16. kongresszus, 江泽民 Jiang Zemin)

Javítanunk kell a szellemi tulajdonvédelem rendszerét. A fenntartható fejlődést rendkívül kiemelten kell kezelnünk, ragaszkodnunk kell a népességszabályozásra, a környezetvédelemre és az erőforrások védelmére vonatkozó alapvető nemzeti politikánkhoz.

完善知识产权保护制度。必须把可持续发展放在十分突出的地位, 坚持计 划生育、保护环境和保护资源的基本国策。(16. kongresszus, 江泽民 Jiang Zemin)

Az infrastruktúra és az ökológiai környezet építéséhez jó alapot kell teremtenünk, szilárdan kell előremozdítanunk, és hangsúlyosnak kell tekinteni a kellő erőfeszítés megtételét ehhez, küzdenünk kell azért, hogy tíz éven belül áttörést érjünk el. 
要打好基础, 扎实推进, 重点抓好基础设施和生态环境建设, 争取十年内 取得突破性进展。(16. kongresszus, 江泽民 Jiang Zemin)

Nyugodtan válaszolunk egy sor országunk szuverenitását és biztonságát érintő váratlan nemzetközi incidensre, legyözzük a kormányzás és a gazdaság területén, valamint a természetben megjelenő nehézségeket és veszélyeket, kiállunk ismételt próbákat, eltávolítunk mindennemú zavart, biztosítjuk, hogy a reform és nyitás, valamint a modernizáció építésének hajója mindvégig a helyes irányba haladjon elöre a hullámokon.

我们从容应对一系列矢系我国主权和安全的国际突发事件, 战胜在政治、 经济领域和自然界出现的困难和风险, 经受住一次又一次考验, 排除各种 干扰, 保证了改革开放和现代化建设的航船始终沿着正确的方向破浪前 进。(16. kongresszus, 江泽民 Jiang Zemin)

Észszerüen használjunk és takarékosan alkalmazzunk valamennyi természeti erőforrást.

合理开发和节约使用各种自然资源。(16. kongresszus, 江泽民 Jiang Zemin)

A nemzetgazdaság ütőeréhez és a nemzetbiztonsághoz kapcsolódó nagy állami vállalatok, az alapvetö infrastruktúra és a fontos természeti erőforrások egyaránt az államot képviselő központi kormányzat felelösségi körébe tartoznak.

矢系国民经济命脉和国家安全的大型国有企业、基础设施和重要自然资源 等, 由中央政府代表国家履行出资人职责。(16. kongresszus, 江泽民 Jiang Zemin)

Ragaszkodunk ahhoz, hogy a társadalomtudományok és a természettudományok egyaránt fontosak, teljes mértékben alkalmaznunk kell a filozófiai társadalomtudományokat a gazdaság- és a társadalomfejlesztés során.

坚持社会科学和自然科学并重, 充分发挥哲学社会科学在经济和社会发展 中的重要作用。(16. kongresszus, 江泽民 Jiang Zemin)

A 17. kongresszuson (2007. október 15-21.) feltűnt az ökológiai civilizáció (生态文明 shengtai wenming) építésének koncepciója, amely attól kezdve folyamatosan visszaköszön a kínai politikai nyelvezetben. Hu Jintao (胡锦涛) pártfőtitkár a környezetvédelemmel kapcsolatban számos konkrét, pozitív eredményröl is beszámolt.

Az energiaforrás-takarékosság és az ökológiai környezet megóvása terén új elörehaladást értünk el. 
能源资源节约和生态环境保护取得新进展。(17. kongresszus, 胡锦涛 $\mathrm{Hu}$ Jintao)

Amellett, hogy meglátjuk a sikert, tisztán fel kell ismernünk, hogy munkánk és az emberek várakozásai között még nem kis különbség van. Az elöre menetel során nem kevés nehézséggel és problémával nézünk szembe, nyilvánvaló: a gazdaság fejlődéséért feláldozott erőforrás-mennyiség és természeti érték túl nagy. 在看到成绩的同时, 也要清醒认识到, 我们的工作与人民的期待还有不小 差距, 前进中还面临不少困难和问题, 突出的是: 经济增长的资源环境代 价过大... (17. kongresszus, 胡锦涛 Hu Jintao)

Ragaszkodnunk kell a termelés fejlesztésének, az élet gazdagításának, az ökológia javításának civilizált fejlődési útjához, építenünk kell egy erőforrás-takarékos, környezetbarát társadalmat, meg kell valósítanunk a gyorsaság és a struktúra, minőség, hatékonyság egységét, valamint a gazdasági fejlődés és a népesség, erőforrások, környezet harmóniáját, hogy a nép jó ökológiai környezetben termeljen és éljen, meg kell valósítanunk a gazdaság és a társadalom fenntartható fejlődését. 坚持生产发展、生活富裕、生态良好的文明发展道路, 建设资源节约型、 环境友好型社会, 实现速度和结构质量效益相统一、经济发展与人口资源 环境相协调, 使人民在良好生态环境中生产生活, 实现经济社会永续发 展。(17. kongresszus, 胡锦涛 Hu Jintao)

Jelentős haladást értünk el a fejlődés módjának átalakításában. A struktúra optimalizálására, a hatékonyság növelésére, a pazarlás csökkentésére, a környezetvédelemre építve 2020-ra 2000-hez képest megnégyszerezzük az egy főre jutó GDP-t.

转变发展方式取得重大进展, 在优化结构、提高效益、降低消耗、保护 环境的基础上, 实现人均国内生产总值到二 0 二 0 年比二 000 年翻两 番。(17. kongresszus, 胡锦涛 Hu Jintao)

Építvén az ökológiai civilizációt, alapjaiban ki kell alakítanunk egy termelési struktúrát, növekedési módszert, fogyasztási modellt, amely energiaforrás-takarékos, és védi az ökológiai környezetet. A körforgásos gazdaság viszonylag nagy méretet öltött, a megújítható energiaforrások aránya észrevehetően emelkedett. A fö szennyező anyagok kibocsátását hatékonyan kontrolláltuk, az ökológiai környezet minősége érezhetően javult.

建设生态文明, 基本形成节约能源资源和保护生态环境的产业结构、增长 方式、消费模式。循环经济形成较大规模, 可再生能源比重显著上升。主 要污染物排放得到有效控制, 生态环境质量明显改善。(17. kongresszus, 胡 锦涛 Hu Jintao) 
Amikor 2020-ra megvalósítjuk a célt, hogy teljeskörüen felépítsük a mérsékelten jómódú társadalmat, hosszú történelmü civilizációnk és fejlődő, nagy szocialista országunk alapvetően megvalósítja az iparosítást, össznemzeti erőnk láthatóan növekedik, hazai piacunk összességében a világelsők között lesz. Olyan ország leszünk, ahol az emberek jóléte minden területen emelkedik, életminőségük láthatóan javul, ökológiai környezetük jó, ahol az emberek még teljesebben élvezhetik a demokratikus jogokat. Olyan ország leszünk, amelynek még magasabb a kulturális értéke és a szellemi törekvése, amely minden területen még jobb, amelynek társadalma még teljesebb életerőt és stabil egyesülést képvisel. Olyan ország leszünk, amely kifelé még nyitottabb, még megnyerőbb, és amely az emberi civilizációért még többet tesz.

到二 0 二 0 年全面建设小康社会目标实现之时，我们这个历史悠久的文明 古国和发展中社会主义大国, 将成为工业化基本实现、综合国力显著增 强、国内市场总体规模位居世界前列的国家, 成为人民富裕程度普遍提 高、生活质量明显改善、生态环境良好的国家, 成为人民享有更加充分民 主权利、具有更高文明素质和精神追求的国家, 成为各方面制度更加完 善、社会更加充满活力而又安定团结的国家, 成为对外更加开放、更加具 有亲和力、为人类文明作出更大贡献的国家。(17. kongresszus, 胡锦涛 $\mathrm{Hu}$ Jintao)

Fokoznunk kell az energiatakarékosságot és az ökológiai környezetvédelmet, és javítani kell a fenntartható fejlődésre való képességünket. Az erőforrások megtakarítása és a környezetvédelem, e két alapvető nemzeti politikánk betartása hatással van az emberek létfontosságú érdekeire, valamint a kínai nemzet fennmaradására és fejlődésére. Az erőforrás-megtakarítás és a környezetbarát társadalom felépítésének kiemelt helyet kell kapnia az iparosodás és a modernizáció stratégiájában, és azt minden egységben és családban végre kell hajtani. Fejleszteni kell az energiaforrások megtakarítását és az ökológiai környezetvédelmet elősegítő törvényeket és politikákat, és fel kell gyorsítani a fenntartható fejlődéssel foglalkozó intézmények kialakítását. Meg kell valósítani az energiatakarékosság és a kibocsátáscsökkentés felelősségvállalási rendszerét. Fejleszteni és támogatni kell a takarékossághoz, a helyettesítéshez, az újrahasznosításhoz és a szennyezés ellenőrzéséhez alkalmazható fejlett technológiákat, a tiszta energia és a megújuló energia fejlesztését, a föld- és vízforrások védelmét, egy tudományos és észszerü energiaforrás-felhasználási rendszer felépítését, valamint az energiaforrások hatékonyabb felhasználását. Fejleszteni kell a környezetvédő ipart. Növelni kell az energiamegtakarításba és a környezetvédelembe történő beruházásokat, összpontosítani kell a víz-, a levegő- és talajszennyezés megelőzésének és ellenőrzésének megerősítésére, valamint a városi és vidéki környezet javítására. Erősíteni kell a vízmegőrzés, az erdőgazdálkodás és a gyepterületek 
kiépítését, az elsivatagosodás és a sziklás sivatagosodás felügyeletét, és ösztönözni kell az ökológiai rendszer helyreállítását. Erősíteni kell a kapacitásépítést az éghajlatváltozás kezelésére, és új hozzájárulást kell tennünk a globális éghajlat védelméhez.

加强能源资源节约和生态环境保护, 增强可持续发展能力。坚持节约资源 和保护环境的基本国策, 矢系人民群众切身利益和中华民族生存发展。必 须把建设资源节约型、环境友好型社会放在工业化、现代化发展战略的突 出位置, 落实到每个单位、每个家庭。要完善有利于节约能源资源和保护 生态环境的法律和政策, 加快形成可持续发展体制机制。落实节能减排工 作责任制。开发和推广节约、替代、循环利用和治理污染的先进适用技 术, 发展清洁能源和可再生能源, 保护土地和水资源, 建设科学合理的能 源资源利用体系, 提高能源资源利用效率。发展环保产业。加大节能环保 投入, 重点加强水、大气、土壤等污染防治, 改善城乡人居环境。加强水 利、林业、草原建设, 加强荒漠化石漠化治理, 促进生态修复。加强应对 气候变化能力建设, 为保护全球气候作出新贡献。(17. kongresszus, 胡锦 涛 Hu Jintao)

Fel kell gyorsítani az egységes, nyitott, versenyképes és szabályszerủ modern piaci rendszer kialakulását, fejleszteni kell a különféle termelési tényezők piacát, tökéletesíteni kell a piaci kínálatot és keresletet, az erőforrások szúkösségét és a környezeti károkkal járó költségeket tükröző termelési tényezőket és az erőforrások árának kialakítását célzó mechanizmusokat, és szabályozottan fejleszteni kell az iparági szövetségeket és a piaci közvetítő szervezeteket. Javítani kell a szociális hitelrendszert.

加快形成统一开放竞争有序的现代市场体系, 发展各类生产要素市场, 完善反映市场供求矢系、资源稀缺程度、环境损害成本的生产要素和资 源价格形成机制, 规范发展行业协会和市场中介组织, 健全社会信用体 系。(17. kongresszus, 胡锦涛 Hu Jintao)

Olyan pénzügyi és adórendszert kell kialakítanunk, amely elősegíti a tudományos fejlődést, valamint létre kell hoznunk és teljeskörüvé kell tennünk az erőforrások kompenzáció ellenében történő felhasználásának rendszerét és az ökológiai környezet kompenzációs mechanizmusát. Ragaszkodnunk kell az általános tervezéshez. Helyesen kell megismernünk és megfelelően kell kezelnünk a kínai színezetủ szocializmusban a fontos kapcsolatokat, és átfogó terveket kell készítenünk a város- és vidékfejlesztésre, a regionális fejlődésre, a gazdasági és társadalmi fejlődésre, valamint az ember és a természet harmonikus fejlődésére... 实行有利于科学发展的财税制度, 建立健全资源有偿使用制度和生态环境 补偿机制。 
必须坚持统筹兼顾。要正确认识和妥善处理中国特色社会主义事业中的重 大矢系, 统筹城乡发展、区域发展、经济社会发展、人与自然和谐发展... (17. kongresszus, 胡锦涛 Hu Jintao)

A demokratikus joguralom, az igazságosság, az őszinteség, a szeretet, a teljes életerő, a stabil rend, az ember és természet közti harmonikus együttélés általános követelménye és közös építése, valamint a belölük való közös részesülés alapelve alapján minden erőnkkel meg kell oldani a nép legföbb, legnyilvánvalóbb, legvalósabb érdekeit érintő problémákat. Azon kell lennünk, hogy megteremtsünk egy olyan helyzetet, ahol minden ember megteszi a tőle telhetőt, megkaphatja, amit akar, és harmóniában élhet, így a fejlődéshez jó társadalmi környezetet biztosítsunk.

要按照民主法治、公平正义、诚信友爱、充满活力、安定有序、人与自然 和谐相处的总要求和共同建设、共同享有的原则, 着力解决人民最矢心 最直接、最现实的利益问题, 努力形成全体人民各尽其能、各得其所而又 和谐相处的局面, 为发展提供良好社会环境。(17. kongresszus, 胡锦涛 $\mathrm{Hu}$ Jintao)

A 17. és a 18. (2012. november 8-14.) kongresszus között félidőben, 2010-re Kína a világ második legnagyobb GDP-vel rendelkező országa lett. Precedens nélküli gazdasági ugrás ez, hiszen 1978-ban még csupán a 48. volt a listán. ${ }^{25}$ Hasonlóan a fejlett országokhoz - beleértve az Amerikai Egyesült Államokat, az Egyesült Királyságot és Japánt - Kína az „előbb szennyez, majd kontrollál” (先污染, 后治理 xian wuran, hou zhili) megközelítést alkalmazta a gazdasági fejlődés során, azaz a környezetvédelem csak akkor került igazán előtérbe, amikor már jelentős gazdasági fejlődést értek el. ${ }^{26}$

A 18. kongresszuson már külön pontként szerepelt a környezetvédelem: „Nyolcadik pont - nagy erőkkel elöremozdítani az ökológiai civilizáció építését 八、大力推进生态文明建设” (összesen 583 szó, a teljes beszéd 12027 szó). A 18. pártfötitkári beszámolóban olyan újszerü kifejezéseket olvashatunk, mint a „Gyönyörü Kína (美丽中国 Meili Zhongguo)” vagy a „zöld fejlődés (绿色发 展 lüse fazhan)". A 18. kongresszussal a környezetvédelem nemcsak a pártfötitkári beszámolókban, hanem a politikai stratégiában is külön pont lett.

A 18. és a 19. (2017. október 18-24.) kongresszusok között, mint láttuk, nagy lépés volt, hogy átdolgozták az 1979-ben hozott környezetvédelmi törvényt. A 19. pártfótitkári beszámolóban is külön fejezet foglalkozott a természettel: „Kilencedik pont - Gyorsítani az ökológiai civilizáció rendszerének reformját, építeni a Gyönyörü Kínát 九、加快生态文明体制改革, 建设美丽中国”

\footnotetext{
25 Moore 2011 (online).

26 Wang 2007: 198.
} 
(összesen 515 szó, a teljes beszéd 13476 szó). Sőt, a kongresszussal párhuzamosan, a 2017-es módosítás során az ökológiai civilizáció javítását beemelték a pártalkotmány preambulumába is. ${ }^{27}$

A környezetvédelem témájában a 19. beszámoló kapcsán kiemelendő a „zöld” szó (绿色 lüse) tizenötszöri említése, és ezzel igen divatos és új keletü környezetvédelmi terminusok beemelése a kongresszusi beszámolóba: „zöld fejlödés (绿色发展 lüse fazhan; 5)”, ,zöld szén (绿色低碳 lüse ditan; 3)”, ,zöld termelés (绿色生产 lüse shengchan; 1)”, ,zöld technika (绿色技术 lüse jishu; 1)”, „zöld bank (绿色金融 lüse jinrong; 1)”, „zöld háztartás (绿色家 庭 lüse jiating; 1)”, „zöld iskola (绿色学校 lüse xuexiao; 1)”, „zöld közösség (绿色社区 lüse shequ; 1)” és ,zöld utazás (绿色出行 lüse chuxing; 1)”. A 19. kongresszuson, a korábbi gyakorlattól eltérően, Xi Jinping konkrét mérföldköveket határozott meg a környezetvédelem területén is:

Az első szakaszban, 2020-tól 2035-ig a teljes körü mérsékelten jómódú társadalom alapjára építve még tizenöt év harcával alapvetően meg kell valósítani a szocialista modernizációt. Akkorra, országunk gazdasági ereje és tudományostechnológiai ereje jelentős mértékben emelkedni fog [...], az ökológiai környezet alapjaiban javul, a Gyönyörü Kína célt alapvetően megvalósítjuk.

第一个阶段, 从二○二○年到二○三五年, 在全面建成小康社会的基础上, 再奋斗十五年, 基本实现社会主义现代化。到那时, 我国经济实力、科技 实力将大幅跃升 […... 生态环境根本好转, 美丽中国目标基本实现。(19. kongresszus, 习近平 Xi Jinping)

A második szakaszban, 2035-től századunk közepéig, a modernizáció alapvető megvalósításának alapjára építve még tizenöt év harcával országunkat gazdag és erős, demokratikus, civilizált, harmonikus és gyönyörü, szocialista, modern országgá kell tennünk. Akkorra, országunk anyagi civilizációja, politikai civilizációja, szellemi civilizációja, társadalmi civilizációja és ökológiai civilizációja teljeskörüen felemelkedik...

第二个阶段, 从二○三五年到本世纪中叶, 在基本实现现代化的基础上, 再奋斗十五年, 把我国建成富强民主文明和谐美丽的社会主义现代化强 国。到那时，我国物质文明、政治文明、精神文明、社会文明、生态文明 将全面提升... (19. kongresszus, 习近平 Xi Jinping)

${ }^{27}$ A Kínai Kommunista Párt alkotmánya: http://www.qstheory.cn/llqikan/2017-12/03/c 1122049483.htm. 


\section{Konklúzió}

Összességében megállapítható, hogy a pártfötitkári beszámolókban a környezetvédelemre a 13. kongresszus óta mindig történik utalás. Ennek terjedelme a környezetvédelmi intézkedések gyakoriságával fokozatosan nőtt, de az is elmondható, hogy a 16. kongresszusig a környezetpolitika súlya a pártfőtitkári beszámolókban nem volt jelentős, külön pontot pedig csak az utóbbi két kongresszuson kapott. A 18. és a 19. kongresszusokon azonban a környezetvédelmi terminusok nemcsak egyre gyakoribbak, de egyre kifinomultabbak is lettek. A kongresszusi nyelvezet és hagyomány folytonosságából és ívéből pedig arra következtethetünk, hogy a környezetvédelem - a 18. és a 19. kongresszusok mintájára - a 20. pártfőtitkári beszámolóban is külön pontot kap majd.

A környezetvédelem immár stabil jelenlétét a pártfötitkári beszámolókban csupán terjedelmüket nézve sem szabad túlértékelnünk. Azt is észre kell vennünk, hogy a pártfötitkári beszámolókban a környezetvédelem említése szinte kivétel nélkül együtt áll a fejlödésre való törekvéssel. A 13. ötéves tervben is feketén-fehéren az áll, hogy Kína, bár elismeri és vállalja globális szerepét a környezetvédelem vonatkozásában, nem adja fel fejlődő ország státuszát. Ez a kategorizálás és elhatárolódás a fejlett országoktól azt is jelenti, hogy más, gazdagabb országoknak nagyobb szerepet kell vállalniuk a környezetvédelemben.

Igaz ugyan, hogy a környezetvédelmi intézkedések kezdetben néhol csak a nemzetközi közvéleménynek szóltak (lásd fehér könyv), néhol pedig hagynak kívánnivalót maguk után (a törvények, rendeletek jogi szövegezése), beátható, hogy az utóbbi években Kína e téren is nagyot fejlödött (2015-ös törvénymódosítás). Fel kell ismernünk azonban azt is, hogy Kínának nincs könnyü dolga. A reform és a nyitáspolitika 1978-as meghirdetése idején Kína fejlettsége több évtizeddel elmaradt a világ vezető országaitól. Jóllehet mára a világ egyik legnagyobb nemzetgazdasága, sok fejlettséget mutató adata (pl. egy före jutó GDPben a 69., a lakosság nagyjából 58\%-a internetfelhasználó, a HDI-t tekintve a világon az 85 .) messze van még az élvonaltól. A kínai vezetésnek így egyszerre kellene az emberek életszínvonalának javításán munkálkodnia és reagálnia a posztmodern nemzetközi környezetvédelmi igényekre és nyomásra. Az egyre környezettudatosabb nemzetközi piacon a kínai gazdaság növekedésének sikerességét döntheti el, hogy Kína milyen választ ad a környezetvédelmi kihívásokra. Az emberiség jövője szempontjából pedig kulcskérdés, hogy Kína egy még soha nem látott környezetvédő gazdaságfejlesztési stratégia kifejlesztésével meg tudja-e oldani a kettős feladatot. 


\section{Elsődleges források}

\section{A pártfötitkári beszámolók internetes forrásai}

13. kongresszus: http://cpc.people.com.cn/GB/64162/64168/64566/65447/4526368.html

14. kongresszus: http://news.ifeng.com/mainland/special/zhonggong18da/content-4/detail_2012_ 11/04/18821874_0.shtml

15. kongresszus: http://news.ifeng.com/mainland/special/zhonggong18da/content-4/detail_2012_ 11/04/18821363_0.shtml

16. kongresszus: http://www.dzwww.com/xinwen/xinwenzhuanti/qzsldzk/xwzx/200211210945. $\mathrm{htm}$

17. kongresszus: http://www.huaxia.com/zt/tbgz/07-082/523727.html

18. kongresszus: http://news.china.com.cn/politics/2012-11/20/content_27165856.htm

19. kongresszus: http://www.xinhuanet.com/politics/19cpcnc/2017-10/27/c_1121867529.htm

\section{Felhasznált másodlagos szakirodalom}

Bradbury, Ian - Kirkby, Richard 1996. „China’s Agenda 21 A critique.” Applied Geography16/2: 97-107. https://doi.org/10.1016/0143-6228(95)00030-5

Cao Huijuan - Hidemichi Fuji - Shunsuke Managi 2013. „Environmental Impact of the 2008 Beijing Olympic Games.” Economics Discussion Papers 2013-30. http://www.economicsejournal.org/economics/discussionpapers/2013-30/file. (utolsó letöltés: 2020.10.19.)

Jordán Gyula 2015. A Kínai Népköztársaság alkotmányainak történeti áttekintése. In: Salát Gergely (szerk.): A kinai alkotmány. Budapest: Typotex Kiadó, 33.

Kusai Sándor Zoltán 2020. „Kína az ökológiai makadámúton.” In: Salát Gergely et. al. (szerk.): Mesterséges természetesség. Környezetkárositás és természetvédelem Ázsiában. Budapest: Typotex Kiadó: 11-29.

Miller, Alice 2012. „The Road to the 18th Party Congress.” China Leadership Monitor 36: 1-7. Wang, Alex 2007. „The Role of Law in Environmental Protection in China: Recent Developments.” UCLA School of Law. Public Law \& Legal Theory Research Paper Series. Research Paper No. 06-46. 8 Vermont Journal of Environmental Law 195: 195-223.

Wang, Lijun 2010. ,The changes of China's environmental policies in the latest 30 years.” Procedia Environmental Sciences 2: 1206-1212. https://doi.org/10.1016/j.proenv.2010.10.131

Zhang Kunmin - Wen Zongguo - Peng Liying 2007. „Environmental Policies in China: Evolvement, Features and Evalutation." China Population, Resources and Environment Volume 17, Issue 2, March. 1-7. https://doi.org/10.1016/S1872-583X(07)60006-0

Zhang Kunmin - Wen Zongguo - Peng Liying 2008. ,Review on environmental policies in China: Evolvement, features, and evaluation.” Front. Environ. Sci. Eng. China 2: 129-141. https:// doi.org/10.1007/s11783-008-0044-6

Zhang Kunmin - Wen Zongguo 2008. „Review and challenges of policies of environmental protection and sustainable development in China." Journal of Environmental Management 88: 1249-1261. https://doi.org/10.1016/j.jenvman.2007.06.019 


\section{Internetes hivatkozások}

11. ötéves terv. https://www.ndrc.gov.cn/xwdt/gdzt/ghjd/quanwen/201402/t20140219_1201612. html (utolsó letöltés: 2020.10.19.)

12. ötéves terv környezetvédelmi vonatkozása. http://www.cn-hw.net/html/sort056/201201/31655. html (utolsó letöltés: 2020.10.19.)

13. ötéves terv. http://www.12371.cn/special/sswgh/wen/\#10 (utolsó letöltés: 2020.10.19.)

A KínaiKommunistaPártalkotmánya.http://www.qstheory.cn/llqikan/2017-12/03/c_1122049483. htm (utolsó letöltés: 2020.10.19.)

A Kínai Népköztársaság Alkotmánya. http://www.gov.cn/govweb/test/2005-06/14/content_6310. htm (utolsó letöltés: 2020.10.19.)

Han Rongliang 2002. „China to Invest 700 Billion-yuan for Improving Urban \& Rural Environment." People's Daily. http://en.people.cn/200201/31/eng20020131_89701.shtml (utolsó letöltés: 2020.10.19.)

Institute for Security \& Development Policy. https://isdp.eu/publication/nccpc-national-congresscommunist-party/ (utolsó letöltés: 2020.10.19.)

Ker, Michelle - Logan, Kate 2014. „New environmental law targets China's local officials.” https://chinadialogue.net/en/pollution/6939-new-environmental-law-targets-china-s-localofficials/ (utolsó letöltés: 2020.10.19.)

Liu Jianqiang 2014. „China's new environmental law looks good on paper.” China Dialogue. https://www.chinadialogue.net/blog/6937-China-s-new-environmental-law-looks-good-onpaper/en (utolsó letöltés: 2020.10.19.)

Moore, Malcolm 2011. „China is the world's second largest economy.” Telegraph. https://www. telegraph.co.uk/finance/economics/8322550/China-is-the-worlds-second-largest-economy. html (utolsó letöltés: 2020.10.19.)

The Poeple's Republic of China National Report on Sustainable Development. http://download. china.cn/en/pdf/development2.pdf (utolsó letöltés: 2020.10.19.)

Világbank adatai https://data.worldbank.org/indicator/NY.GDP.MKTP.CD?most_recent_value_ desc=true (utolsó letöltés: 2020.10.19.)

World Trade Organisation [álláspont a kereskedelem és a környezet kapcsolatáról]. https://www. wto.org/english/tratop_e/envir_e/envir_e.htm (utolsó letöltés: 2020.10.19.) 
